\title{
PRESENCE OF THE NEARCTIC WATER BOATMAN TRICHOCORIXA VERTICALIS VERTICALIS (FIEBER, 1851) (HETEROPTERA, CORIXIDAE) IN THE ALGARVE REGION (S PORTUGAL)
}

\author{
J. Sala* \& D. Boix*
}

\begin{abstract}
This paper describes the presence of the nearctic water boatman Trichocorixa verticalis verticalis in southern Portugal. This species has been cited recently for the first time in Europe from individuals captured in southern Spain. This species, native to Atlantic coast of America, has also been cited from New Caledonia and South Africa, and has been found in the open sea. Two kinds of introduction are reported for this species: involuntary introduction with exotic fish, and passive dispersion through marine currents and severe storms. The possibility of this kind of introduction in Europe is discussed.
\end{abstract}

Key words: Heteroptera, Corixidae, Trichocorixa verticalis verticalis, Iberian Peninsula, exotic species, dispersal mechanism.

\section{RESUMEN}

Presencia del Coríxido neártico Trichocorixa verticalis verticalis (Fieber, 1851) (Heteroptera, Corixidae) en el Algarve (S Portugal)

Esta nota describe la presencia del coríxido neártico Trichocorixa verticalis verticalis en el sur de Portugal. Recientemente, esta especie ha sido citada por primera vez en Europa de ejemplares capturados en el sur de España. Esta especie, nativa de la costa atlántica americana, también ha sido citada en Nueva Caledonia y África del Sur, y se ha encontrado en mar abierto. Se conocen dos vías de introducción de esta especie: introducción involuntaria a través de peces exóticos y dispersión pasiva a través de corrientes marinas y fuertes tormentas. Se discuten las posibilidades de estas dos vías de introducción en Europa.

Palabras claves: Heteroptera, Corixidae, Trichocorixa verticalis verticalis, Península Ibérica, especie exótica, mecanismos de dispersión.

\section{Introduction}

Trichocorixa Kirkaldy, 1908 is a strictly nearctic and neotropical genus distributed from Canada to Argentina. Trichocorixa verticalis (Fieber, $1851)$ is a corixid divided into several subspecies throughout North America and the Caribbean islands, inhabiting preferably brackish or saline waters (Sailer, 1948). This species is considered, with the dragonfly Erythrodiplax berenice (Drury, 1770) and several insect larvae, as an extremely euryhaline insect (Hutchinson, 1993). The nomi-

* Instituto de Ecología Acuática, Universitat de Girona, Campus Montilivi, E-17071, Girona, Spain. Teléfono: +34 972418 466. E-mail: j.sala@menta.net. E-mail: dani.boix@udg.es. 


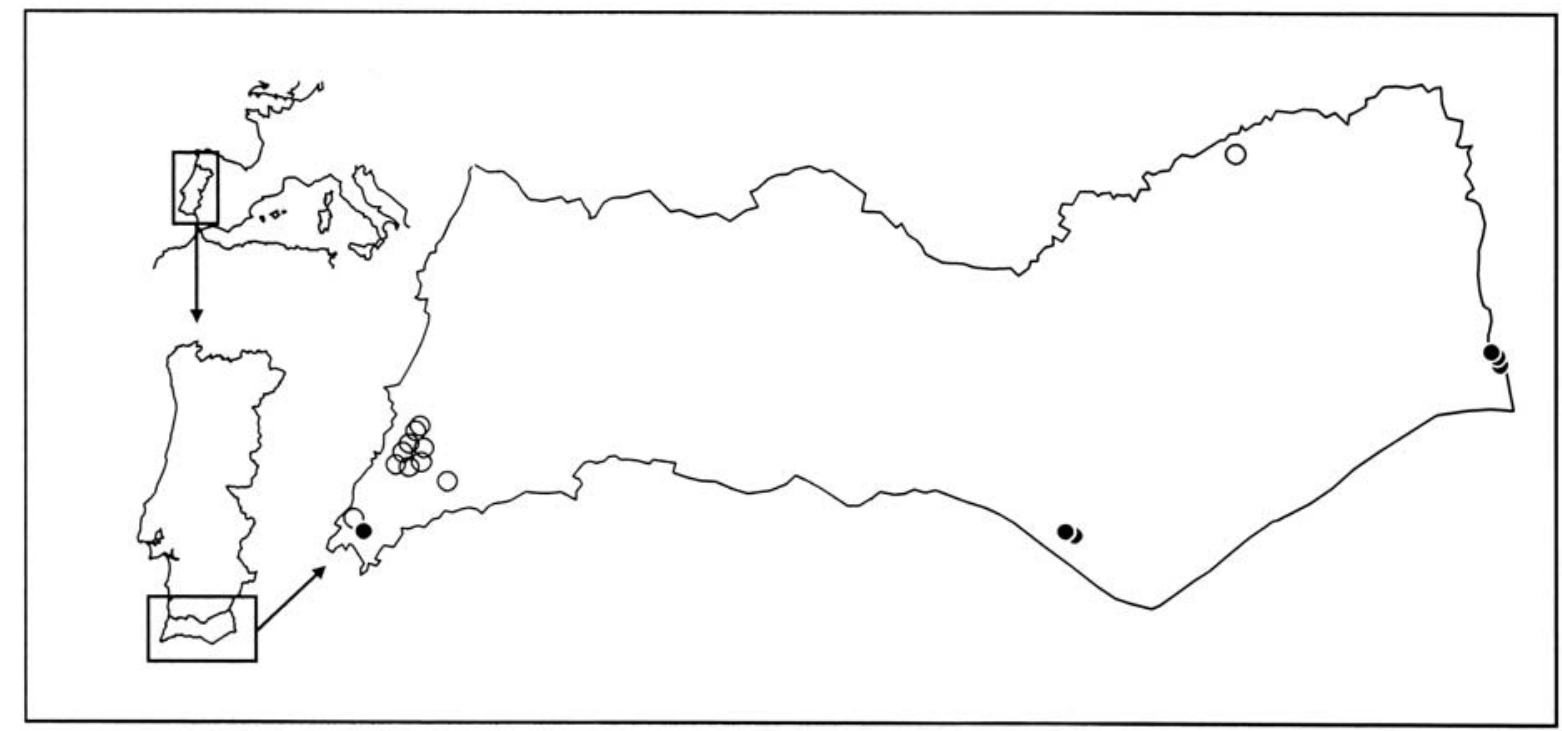

Fig. 1. - Map of the sampled temporary ponds in the Algarve region. Black dots show sites with presence of Trichocorixa verticalis verticalis, and empty dots show sites without its presence.

Fig. 1.- Mapa de las lagunas temporales muestreadas en la región del Algarve. Los puntos negros muestran las localidades con presencia de Trichocorixa verticalis verticalis, y los puntos vacíos muestran localidades sin su presencia.

nal subspecies, T. v. verticalis (Fieber, 1851), is distributed throughout the Atlantic coast from Labrador to the north of Mexico, and the Caribbean islands (Sailer, 1948; Jansson, 2002). The presence of $T$. $v$. verticalis outside the American continent is reported from New Caledonia (Jansson, 1982), several sites in the KwaZulu-Natal region in South Africa (Nzimane River, Umhlatuze River and Charter's Creek; Jansson \& Reavell, 1999) and in the province of Cádiz, Spain (Sanlúcar de Barrameda; Günther, 2004). Other species of the genus Trichocorixa are also found outside their distribution area, such as T. reticulata (Guérin-Ménéville, 1857) in Hawaii (Sailer, 1948) or T. kanza Sailer, 1948 in Mali (Jansson \& Reavell, 1999). Although the presence of T. reticulata from Shanghai is also reported (Hutchinson, 1931; Sailer, 1948), Jansson (1982) doubts the validity of the citation and considers that they are mislabeled specimens from the Hawaiian Islands.

In 2002, adults of the corixid Trichocorixa verticalis verticalis were observed in a puddle on a path on the campus of the Universidade do Algarve, in Gambelas (S Portugal). Later on, during a sampling campaign on large branchiopods, the same species was detected in four temporary ponds, one in Gambelas and three in Castro Marim. Finally, checking macroinvertebrate samples from another study on large branchiopods carried out in the Algarve between 1997 and 1998 (Machado et al., 1999; Machado, pers. comm., 2003), individuals of the same species were identified from a temporary pond near Sagres.

\section{Material and Methods}

All the individuals of adult corixids in qualitative macroinvertebrate samples of 16 temporary ponds of the Algarve region (Fig. 1) were sorted and identified under a stereomicroscope. Individuals were captured with a dip net of 30.5 $\mathrm{cm}$ diameter and a mesh size of $1 \mathrm{~mm}$. Sailer (1948), Jansson (1986) and Nieser et al. (1994) were used to identify the corixids. Other types of aquatic ecosystems were not sampled, because all samples corresponded to temporary pond community studies. The names of the ponds of Vila do Bispo council follow Alcazar (1998) and those of Castro Marim council follow Cardoso et al. (2000). 
Table 1.- Presence of corixid species in several temporary ponds in the Algarve region.

Tabla 1.- Presencia de especies de coríxidos en diversas lagunas temporales en la región del Algarve.

\begin{tabular}{|c|c|c|c|c|c|c|c|c|c|}
\hline Council and pond & $\begin{array}{l}\text { hocorixa } \\
\text { is verticalis }\end{array}$ & $\begin{array}{l}\text { Corixa } \\
\text { affinis }\end{array}$ & $\begin{array}{c}\text { Corixa } \\
\text { panzeri }\end{array}$ & $\begin{array}{c}\text { Hesperocorixa } \\
\text { linnaei }\end{array}$ & $\begin{array}{l}\text { Sigara } \\
\text { selecta }\end{array}$ & $\begin{array}{c}\text { Sigara } \\
\text { stagnalis }\end{array}$ & $\begin{array}{c}\text { Sigara } \\
\text { nigrolineata }\end{array}$ & $\begin{array}{c}\text { Sigara } \\
\text { scotti }\end{array}$ & $\begin{array}{c}\text { Sigara } \\
\text { lateralis }\end{array}$ \\
\hline \multicolumn{10}{|l|}{ Vila do Bispo } \\
\hline \multicolumn{10}{|l|}{ Lagoa do Monte } \\
\hline do Vale Santo (G3) & & + & & & + & & & + & + \\
\hline Lagoa Funda (G12) & & & + & & & & & & + \\
\hline Lagoa G14 & & + & & & & & & & + \\
\hline Lagoa G15 & & & & & & & & + & + \\
\hline Lagoa G16 & & + & + & & & & & & + \\
\hline Lagoa G17 & & & & & & & & + & + \\
\hline Lagoa G19 & & & & & & & & + & \\
\hline Lagoa G21 & & & & & & & & + & + \\
\hline \multicolumn{10}{|l|}{ Lagoa do Pinhal } \\
\hline de Sagres (G37) & + & & & & & & & & + \\
\hline Lagoa G42 & & + & & + & & & & + & + \\
\hline Lagoa de Budens & & + & + & & & + & & + & + \\
\hline \multicolumn{10}{|l|}{ Faro } \\
\hline Lagoa do Pinhal de Gambelas & + & & & & & & + & & + \\
\hline \multicolumn{10}{|l|}{ Castro Marim } \\
\hline Lagoa G & + & + & & & & & & & + \\
\hline Lagoa J & + & & & & & & & & + \\
\hline Lagoa N & + & + & & & & & & & + \\
\hline \multicolumn{10}{|l|}{ Alcoutim } \\
\hline Lagoa de Martinlongo & & + & & & & & & & + \\
\hline
\end{tabular}

\section{Results}

The material examined consists of:

\section{Trichocorixa verticalis verticalis (Fieber, 1851)}

- Lagoa do Pinhal de Sagres, Sagres (Vila do Bispo). UTM (x,y): (29S 0503546, 4099224). 60 m a.s.1. 11-XII-1997, 9 males and 14 females. M. Machado, M. Cristo \& L. Cancela de Fonseca leg. Temporary pond.

- Campus of the Universidade do Algarve, Gambelas (Faro). UTM (x,y): (29S 0591169, 4100433). 20 m a.s.1. 19-IX-2002, 2 males and 5 females. J. Sala leg. Puddle.

- Lagoa do Pinhal de Gambelas, Gambelas (Faro). UTM (x,y): (29S 0590647, 4101007). $20 \mathrm{~m}$ a.s.1. 08-XI-2002, 1 male and 2 females. M. Machado \& J. Sala leg.; 21-XI-2002, 1 male. M. Machado \& J. Sala leg.; 23-X-2003, 3 males and 3 females. M. Machado leg. Temporary pond.

- Lagoa G of the Reserva Natural do Sapal de Castro Marim e Vila Real de Santo António, Castro Marim (Castro Marim) UTM (x,y): (29S 0639448, 4122508). 5 m a.s.1. 07-XI-2002, 1 male. M. Machado \& J. Sala leg. Temporary pond.

- Lagoa J of the Reserva Natural do Sapal de Castro Marim e Vila Real de Santo António, Castro Marim (Castro Marim). UTM (x,y): (29S 0639666, 4122057). 5 m a.s.l. 07-XI2002, 7 males and 3 females M. Machado \& J. Sala leg. Temporary pond.
- Lagoa N of the Reserva Natural do Sapal de Castro Marim e Vila Real de Santo António, Castro Marim (Castro Marim). UTM (x,y): (29S 0639346, 4122761). 5 m a.s.1. 07-XI-2002, 42 males and 20 females. M. Machado \& J. Sala leg. Temporary pond.

The coexistence of Trichocorixa verticalis verticalis with Palaearctic species of Corixidae was observed in all the ponds, mainly with Sigara lateralis (Leach, 1817) and Corixa affinis Leach, 1817 (Table 1). Twelve species of Corixidae are reported from the Algarve region (Nieser \& Montes, 1984; Jansson, 1986): Micronecta scholtzi (Fieber, 1860), Corixa affinis, C. iberica Jansson, 1981, C. panzeri (Fieber, 1848), Hesperocorixa moesta (Fieber, 1848), Parasigara transversa (Fieber, 1848), Sigara fossarum (Leach, 1817), S. lateralis, S. limitata (Fieber, 1848), S. nigrolineata (Fieber, 1848), $S$. selecta (Fieber, 1848), and S. semistriata (Fieber, 1848). This study also reveals the presence of Hesperocorixa linnaei (Fieber, 1848), Sigara stagnalis (Leach, 1817) and S. scotti (Douglas \& Scott, 1868 ) in the Algarve (Table 1). Physical and chemical information on some Algarve temporary ponds can be found in Table 2 . 
Table 2.- Physical and chemical data for some Algarve temporary ponds.

Tabla 2.- Datos físicos y químicos de algunas lagunas temporales del Algarve.

\begin{tabular}{lcccc}
\hline & $\begin{array}{c}\text { Number } \\
\text { of samples }\end{array}$ & $\begin{array}{c}\text { Temperature } \\
\left.\mathbf{(}^{\mathbf{O}} \mathbf{C}\right)\end{array}$ & $\begin{array}{c}\text { Conductivity } \\
(\boldsymbol{\mu S} / \mathbf{c m})\end{array}$ & $\mathbf{p H}$ \\
\hline Lagoa do Monte do Vale Santo (G3) & 25 & $19.4(12.0-30.0)$ & $651(200-3800)$ & $7.8(6.8-9.3)$ \\
Lagoa do Pinhal de Sagres (G37) & 12 & $16.3(13.0-22.0)$ & $1230(800-1700)$ & $8.4(8.2-8.6)$ \\
Lagoa do Pinhal de Gambelas & 2 & $12.6(12.1-13.1)$ & $44(3-85)$ & - \\
Lagoa G (Castro Marim) & 1 & $14.7(-)$ & $1000(-)$ & $8.0(-)$ \\
Lagoa J (Castro Marim) & 2 & $17.0(13.1-20.8)$ & $2500(-)$ & $7.3(7.0-7.6)$ \\
Lagoa N (Castro Marim) & 1 & $15.1(-)$ & $240(-)$ & $8.5(-)$ \\
\hline
\end{tabular}

\section{Discussion}

The presence of Trichocorixa verticalis verticalis in the south of Portugal represents the second citation of this genus in Europe. This species has been cited recently in the province of Cádiz, Spain (Günther, 2004). Thus, the citations in Portugal verify the establishment of this exotic species in the south of the Iberian Peninsula. T. v. verticalis differs from the rest of the Palaearctic species of Corixidae in that it is less than $5.5 \mathrm{~mm}$ long, and has sinistral asymmetry, triangular pala, and an apically produced protibia in males (only 2 Palaearctic genera present sinistral asymmetry: Corixa Geoffroy, 1762 and Heliocorisa Lundblad, 1928. Corixa spp. have body lengths superior to $7 \mathrm{~mm}$, and Heliocorisa spp. do not have the pala and the tibia as above).

The discovery of this species in the Algarve region from at least 1997 shows that the presence of T. v. verticalis in the Iberian Peninsula cannot be considered occasional, although the sporadic prospections performed for this and other studies (Günther, 2004) do not allow us either to define with clarity the actual distribution of this species nor to know if the different populations have settled in the area.

The genus Trichocorixa has been cited several times outside its distribution area, being present in Africa, the Pacific region and now Europe. The presence of $T . v$. verticalis and $T$. kanza in New Caledonia, South Africa and Mali has been related to the introduction of Gambusia affinis (Baird \& Girard, 1853) (Jansson, 1982; Jansson \& Reavell, 1999). Two species of Gambusia (G. affinis and $G$. holbrooki Girard, 1859) have been widely introduced worldwide as a biological control of mosquito populations. These two species are sympatric with $T$. v. verticalis and T. kanza: G. holbrooki is distributed along the east coast of USA from New Jersey to Florida, while G. affinis replaces it further westwards along the coast of the Gulf of Mexico (Rauchenberger, 1989). On the Iberian Peninsula, $G$. holbrooki was introduced in 1921 (Nájera, 1944) and arrived in Portugal during the 1930s (Boto, 1932). On the Iberian Peninsula, another exotic fish is also present, Fundulus heteroclitus (Linnaeus, 1766), which is also sympatric with $T$. v. verticalis in North America, being distributed, in its native area, from Canada to Florida along the Atlantic coast. Fundulus heteroclitus was introduced supposedly in the province of Huelva in 1973, and is now distributed in the Spanish provinces of Cádiz and Huelva, and in the Portuguese region of the Algarve (GutierrezEstrada et al., 1998). Fundulus heteroclitus and G. holbrooki are euryhaline species, although $F$. heteroclitus inhabits waters with higher salinity. On the Iberian Peninsula, we must allow for the possibility of the accidental introduction of $T$. v. verticalis with $F$. heteroclitus, and not only the hypothesis of introduction with $G$. holbrooki. In fact, the coincidence of the distributions of $T$. v. verticalis and $F$. heteroclitus in the Iberian Peninsula, and the absence of citations of $T$. $v$. verticalis in the recent revisions of the distribution of Corixidae on the Iberian Peninsula (Nieser \& Montes, 1984; Baena \& Vázquez, 1986; Nieser et al., 1994) or in Europe (Jansson, 1986; Polhemus et al., 1995) makes it more plausible to consider that, if introduced with an exotic fish, it could be with $F$. heteroclitus. 
Although the citations of several species of Trichocorixa outside the American continent seem to be related to anthropic activity, Hutchinson (1931) and Sailer (1948) do not reject the hypothesis that the presence of $T$. reticulata in the Hawaiian islands could be caused by a dispersion due to the marine current between the Pacific coast of the continent and the Hawaiian islands. Nevertheless, these authors also admit the possibility that its arrival in the Hawaiian islands could be due to an anthropic factor, and Jansson (1982) considers rather improbable the hypothesis of marine dispersion. On the other hand, Sailer (1948) describes the colonization of the island of Bermuda by $T$. v. verticalis transported by a severe storm in 1927.

Trichocorixa verticalis verticalis has the capacity to inhabit saline environments (Wurtsbaugh, 1992; Aiken \& Malatestinic, 1995) or even to survive in the open sea (Hutchinson, 1931; Gunter \& Christmas, 1959). In fact, there are twelve genera of Corixidae which can inhabit saline waters, but only the genus Trichocorixa has been found in the open sea, and T. verticalis has a high osmoregulatory ability (Scudder, 1976). This ability to survive in the open sea and the possibility of being transported by severe storms implies that natural transportation of $T$. v. verticalis cannot be completely ruled out (Hutchinson, 1993) and it could be the way of introduction of $T$. v. verticalis into Europe. The existence of the Gulf Current between the American and European Atlantic coasts, and the predominantly easterly winds in the Atlantic support this hypothesis. According to that, the occasional presence of the migratory butterfly Danaus plexippus (Linnaeus, 1758) on the Western European coast is related to these predominant winds (Vanholder, 1996; Fernández Vidal, 2002). The wind has been considered an important way for the intercontinental dispersion of several insect species, as in the dispersion of the orthopteran Schistocerca gregaria (Forskål, 1775) between Africa and the Caribbean (Rosenberg \& Burt, 1999), or the dispersion of the lepidopteran $D$. plexippus between New Caledonia and Australia (Clarke \& Zalucki, 2004).

\section{ACKNOWLEDGEMENTS}

We are grateful to Margarida Machado for the gift of material, field data and valuable advice, to Katarina Magnusson for her help with the references, and to João Reis, João Gomes, Mònica Martinoy and Josep Pascual for valuable comments.

\section{References}

Aiken, R. B. \& Malatestinic, N., 1995. Life history, gonad state, and changes in functional sex ratio in the salt-marsh waterboatman, Trichocorixa verticalis (Fieber) (Heteroptera: Corixidae). Canadian Journal of Zoology, 73: 552-556.

AlCAZAR, R., 1998. Impactos da agricultura nas lagoas temporárias do Parque Natural do Sudoeste Alentejano e Costa Vicentina. Master's Thesis. Universidade de Lisboa. Lisboa. $47 \mathrm{pp}$.

Baena, M. \& VÁzquez, M. A., 1986. Catálogo preliminar de los heterópteros acuáticos ibéricos (Heteroptera: Nepomorpha, Gerromorpha). Graellsia, 42: 61-89.

Вото, R., 1932. Distribuição de Gambúsia em Benavente e Salvaterra de Magos. Travaux de la Station de Biologie Maritime de Lisbonne, 30: 245249.

Cardoso, I. A., Abreu, A. \& Machado, M., 2000. Resultados da pesquisa de crustáceos filópodes nas lagoas e charcos temporários de Castro Marim. Technical report. Reserva Natural do Sapal de Castro Marim e Vila Real de Santo António. Castro Marim. 9 pp.

Clarke, A. R. \& Zalucki, M. P., 2004. Monarchs in Australia: on the winds of a storm? Biological Invasions, 6: 123-127.

Fernández Vidal, E. H., 2002. La Danaus plexippus (Linnaeus, 1758) en Galicia (España). Nuevos datos y noticias sobre la "Operación Monarca" (Lepidoptera: Danaidae). Boletín de la Sociedad Entomológica Aragonesa, 31: 243-246.

GunTER, G. \& ChristMAS, J.Y., 1959. Corixid insects as part of the offshore fauna of the sea. Ecology, 40(4): 724-725.

GÜNTHER, H., 2004. Trichocorixa verticalis verticalis (Fieber), eine nearktische Ruderwanze in Europa. Mitteilungen des Internationalen Entomologischen Vereins, 29(1/2): 45-49.

Gutiérrez-Estrada, J. C., Prenda, J., Oliva, F. \& FERNÁNDEZ-DELGADO, C., 1998. Distribution and habitat preferences of the introduced mummichog Fundulus heteroclitus (Linneaus) in south-western Spain. Estuarine, Coastal and Shelf Science, 46: 827-835.

Hutchinson, G. E., 1931. On the occurrence of Trichocorixa Kirkaldy (Corixidae, HemipteraHeteroptera) in salt water and its zoo-geographical significance. The American Naturalist, 65: 573574.

Hutchinson, G. E., 1993. The Zoobenthos. John Wiley \& Sons. New York. 944 pp.

JANSSON, A., 1982. Notes on some Corixidae (Heteroptera) from New Guinea and New Caledonia. Pacific Insects, 24(1): 95-103. 
JANSSON, A., 1986. The Corixidae (Heteroptera) of Europe and some adjacent regions. Acta Entomologica Fennica, 47: 1-94.

JANSSON, A., 2002. New records of Corixidae (Heteroptera) from northeastern USA and eastern Canada, with one new synonymy. Entomologica Fennica, 13: 85-88.

Jansson, A. \& Reavell, P. E., 1999. North American species of Trichocorixa (Heteroptera: Corixidae) introduced into Africa. African Entomology, 7(2): 295-297.

Machado, M., Cristo, M. \& CAncela da Fonseca, L., 1999. Non-cladoceran branchiopod crustaceans from southwest Portugal. I. Occurrence notes. Crustaceana, 72(6): 591-602.

NÁJERA, L., 1944. Sobre la identificación de la Gambusia holbrooki. Boletín de la Real Sociedad Española de Historia Natural, 42: 51-55.

Nieser, N. \& MonTes, C., 1984. Lista faunística y bibliográfica de los Heterópteros acuáticos (Nepomorpha \& Gerromorpha) de España y Portugal. Asociación Española de Limnología. Madrid. 66 pp.

Nieser, N., BAena, M., Martínez-Avilés, J. \& Millán, A., 1994. Claves para la identificación de los heterópteros acuáticos (Nepomorpha \& Gerromorpha) de la Península Ibérica. Con notas sobre las espécies de las Islas Azores, Baleares, Canarias y Madeira. Asociación Española de Limnología. Madrid. 112 pp.

Polhemus, J. T., Jansson, A. \& Kanyukova, E., 1995. Infraorder Nepomorpha - water bugs. In: B. Aukema \& C. Rieger (eds.). Catalogue of the Heteroptera of the Palaearctic Region. Volume 1. Enicocephalomorpha, Dipsocoromorpha, Nepomorpha, Gerromorpha and Leptopodomorpha. The Netherlands Entomological Society. Amsterdam: 13-76.
RAUCHENBERGER, M., 1989. Systematics and biogeography of the genus Gambusia (Cyprinodontiformes: Poecilidae). American Museum Novitates, 2951: 1-74.

Rosenberg, J. \& Burt, P. J. A., 1999. Windborne displacements of Desert Locusts from Africa to the Caribbean and South America. Aerobiologia, 15: 167-175.

SaILER, R. I., 1948. The genus Trichocorixa (Corixidae, Hemiptera). In: H. B. Hungerford. The Corixidae of the Western Hemisphere (Hemiptera). The University of Kansas Science Bulletin, 32: 289-407.

SCUDDER, G. G. E., 1976. Water-boatmen of saline waters (Hemiptera: Corixidae). In: L. Cheng (ed.). Marine insects. North-Holland Publishing Company. Amsterdam: 263-289.

VANHOLDER, B., 1996. The migration of Danaus plexippus (Linnaeus, 1758) during October 1995 in the UK (Lepidoptera: Nymphalidae, Danainae). Nota Lepidopterologica, 19(1/2): 129-140.

WurtsBaugh, W. A., 1992. Food-web modification by an invertebrate predator in the Great Salt Lake (USA). Oecologia, 89: 168-175. 